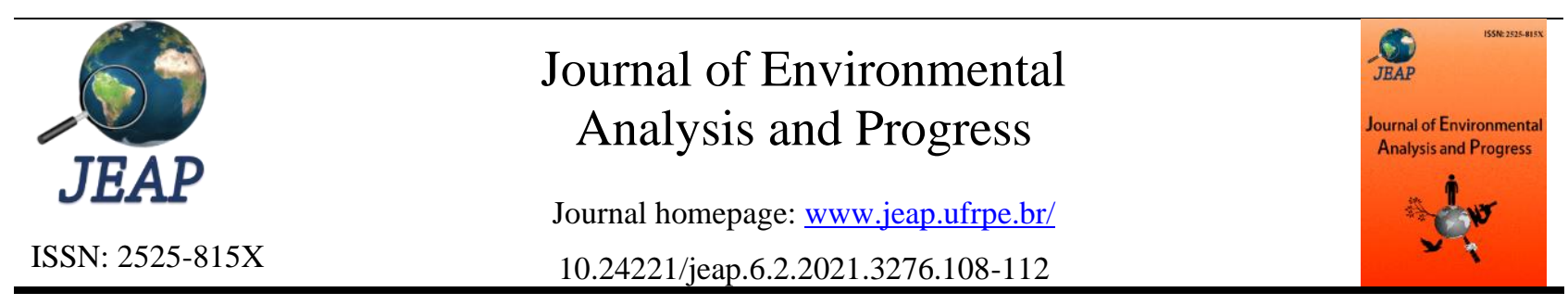

\title{
Vacant rooms? The secondary use of stem-galls by ants in Eremanthus erythropappus (Asteraceae)
}

\author{
Jean Carlos Santos ${ }^{\mathrm{a}}$, Pietro Kiyoshi Maruyama ${ }^{\mathrm{b}}$, GeraldoWilson Fernandes $^{\mathrm{b}}$ \\ ${ }^{a}$ Universidade Federal de Sergipe-UFS, Departamento de Ecologia. Campus São Cristóvão, Cidade Universitária Prof. \\ José Aloísio de Campos. Av. Marechal Rondon, s/n, Bairro Jardim Rosa Elze, São Cristóvão, Sergipe, Brazil. CEP: \\ 49100-000. E-mail: jcsantosbio@gmail.com. \\ ${ }^{\mathrm{b}}$ Universidade Federal de Minas Gerais-UFMG, Departamento de Genética, Ecologia e Evolução, Instituto de Ciências \\ Biológicas. Av. Antonio Carlos, n. 6627, Pampulha, Belo Horizonte, Minas Gerais, Brazil. CEP: 30161-901. E-mail: \\ pietrokiyoshi@gmail.com, gw.fernandes@gmail.com.
}

A R T I C L E I N F O
Received 27 Mar 2020

Accepted 03 Mar 2021

Published 13 Abr 2021

\begin{abstract}
A B S T R A C T
Galls are atypical proliferations of plant tissue induced by highly specialized herbivores, such as some insect groups. Although gall inducers create these structures for their own purpose (food, habitat, protection against natural enemies, and harsh weather), many other organisms can use galls as secondary inhabitants. The creation of new and better habitats with ameliorated micro-environmental conditions allows for the use of many other organisms, and as such, some galling insects are considered "micro" ecosystem engineers. This study characterized the occurrence of ants in microhabitats created by a gall-inducing cecidomyiidae associated with Eremanthus erythropappus (DC.) Mac. Leish (Asteraceae). It was 153 individuals of ants belonging to three species in 19 galls (9.5\%) from the 200 galls sampled. The most common ant species found was Myrmelachista gallicola Mayr (Formicinae), including a single queen and larvae individuals. Galls occupied by these ants were $11.5 \%$ larger compared to unoccupied galls (gall diameter: occupied galls - $10.00 \pm$ $2.09 \mathrm{~mm}$; unoccupied galls $-8.97 \pm 1.90 \mathrm{~mm}$ ). Abandoned galls might promote the diversity of other organisms, especially for opportunistic dwellers such as ants.

Keywords: Community structure, ecosystem engineers, insect galls, rupestrian grasslands, Serra do Cipó.
\end{abstract}

\section{Introduction}

Galls are atypical proliferations of plant tissue induced by specialized herbivores (Shorthouse et al., 2005). Although gall inducers create these structures for their own purpose, many organisms can use galls as secondary inhabitants (Mani, 1964; Craig et al., 1991; Crawford et al., 2007; Maruyama et al., 2012, Giannetti et al., 2019). Gall inducers create new habitats with micro-environmental changes which are used by other organisms, and as such they are considered "micro" ecosystem engineers (Sanver \& Hawkins, 2000; Crawford et al., 2007; Maruyama et al., 2012). Secondary dwellers can use galls as refuges from predators, sites for preferential foraging and protection from unfavourable environmental conditions (Sanver \& Hawkins, 2000; Yamazaki \& Sugiura, 2008; Sugiura \& Yamazaki, 2009). Distinct groups of arthropods have been reported as secondary inhabitants in galls (see Mani , 1964), and ants seems to be a common group found in galls (Wheeler \& Longino, 1988; Craig et al., 1991; Araújo et al., 1995; Crawford et al., 2007; Maruyama et al., 2012).

In this study, it was characterized the gall induced by a still undescribed cecidomyiid midge species on Eremanthus erythropappus (DC.) Mac. Leish (Asteraceae) and its use by ants in a rupestrian grassland vegetation in southeastern Brazil. Specifically, this study addresses the following questions: (a) how the cecidomyiid midge modify the stem morphology in the host plant?; (b) which ant species occupy the galls in the study area?; and (c) is there any relationship among gall occupation by ants and gall-size?

\section{Materials and methods}

Eremanthus erythropappus (Asteraceae), known as "Candeia", is a treelet found in forest borders and grasslands (Figure 1ab) at altitudes 
ranging from 1,000 to $1,700 \mathrm{~m}$ a.s.l. in the Espinhaço mountain range in Brazil. This host species often has stem galls induced by the undescribed cecidomyiid midge. The galls are greenish and brown in colour, globoid and induce on the stems of the plant (Figure 1c). This
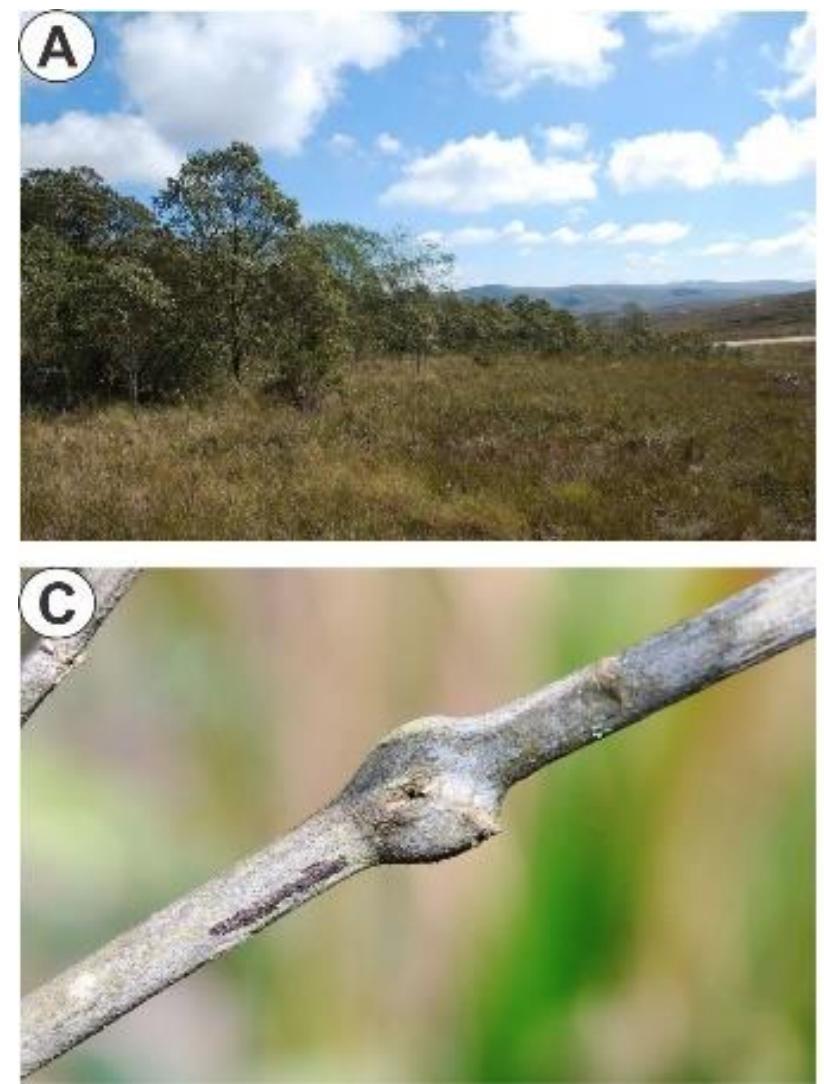

Figure 1. A. Study site, cerrado from Serra do Cipó, Minas Gerais, Brazil; B. Individual of Eremanthus erythropappus (DC.) Mac. Leish (Asteraceae); C. Gall of undescribed gall-inducing cecidomyiid species; D. Cross section of a gall showing some workers of Myrmelachista gallicola (Formicinae). Font: Santos, J. C. (2021).

It was 200 abandoned galls from 40 Eremanthus erythropappus plants (five galls per plant individual). The modification induced by the cecidomyiid midge on the plant stem was evaluated by comparing the maximum diameter of the gall and the diameter of the nearest healthy portion of the stem. Measurement was taken using a digital calliper (error $0.01 \mathrm{~mm}$ ) and compared by pairedsample t test (Zar, 1999). After the measurements, it was opened the galls and checked for the occurrence of ants. When ants were found, we counted the number of individuals and then classified them according to their caste or developing phase (larvae, workers, and queens). The diameters of occupied and unoccupied galls were also compared using paired-sample $t$-test within the same plant individual (Zar, 1999). All ants were preserved in alcohol $70 \%$ and reference material was deposited at the Universidade Federal de Minas Gerais. cecidomyiid gall and its host plant are very common in the southern portion of the Espinhaço Range, Brazil (Coelho et al., 2009). Field collection was carried out in March 2011 in the Serra do Cipó, Minas Gerais, Brazil.
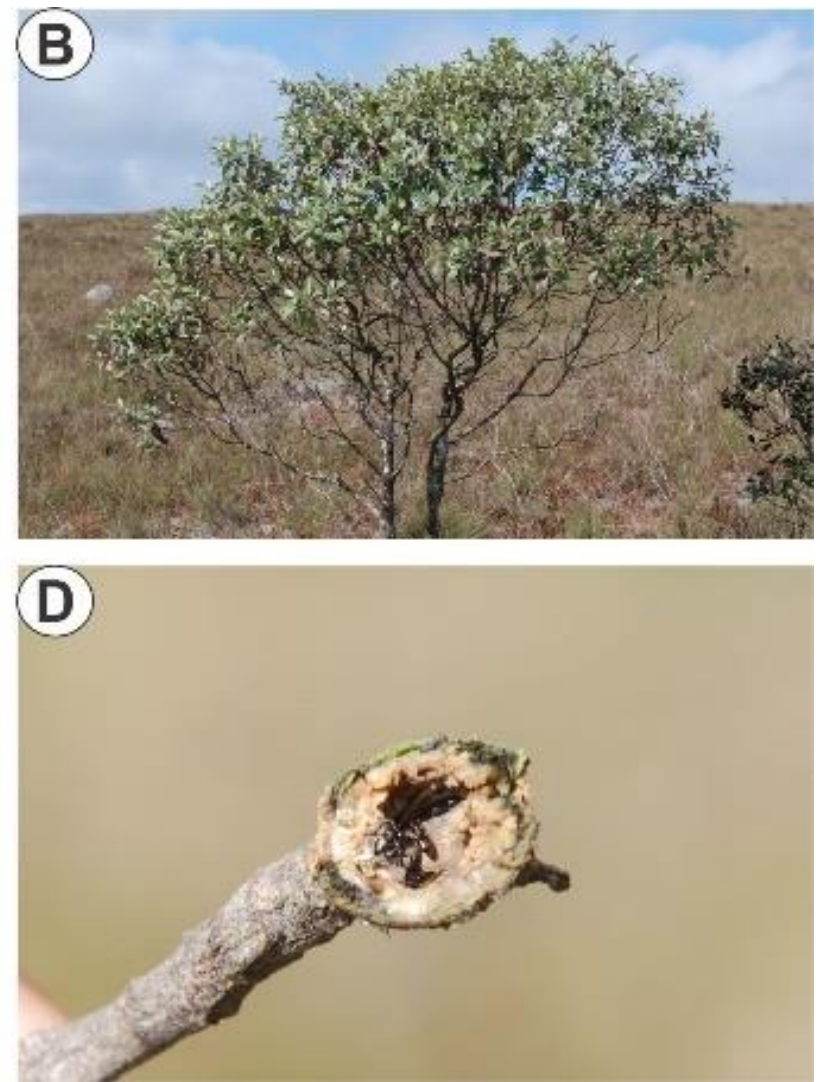
Neither pupae nor alate individuals were found in the galls. For C. torosa, it was founded a single queen with two workers in a gall. Finally, we found a single queen of the unidentified ant species. Ants typically occupied galls $11.5 \%$ larger, considering the diameter [occupied galls $-10.00 \pm 2.09 \mathrm{~mm}$ (mean $\pm \mathrm{SD}), \mathrm{n}=19$; unoccupied galls $-8.97 \pm 1.90$ $\mathrm{mm}($ mean $\pm \mathrm{SD}), \mathrm{n}=181 ; \mathrm{t}=2.212, \mathrm{df}=198, p=$ 0.03 , Figure $2 b]$.
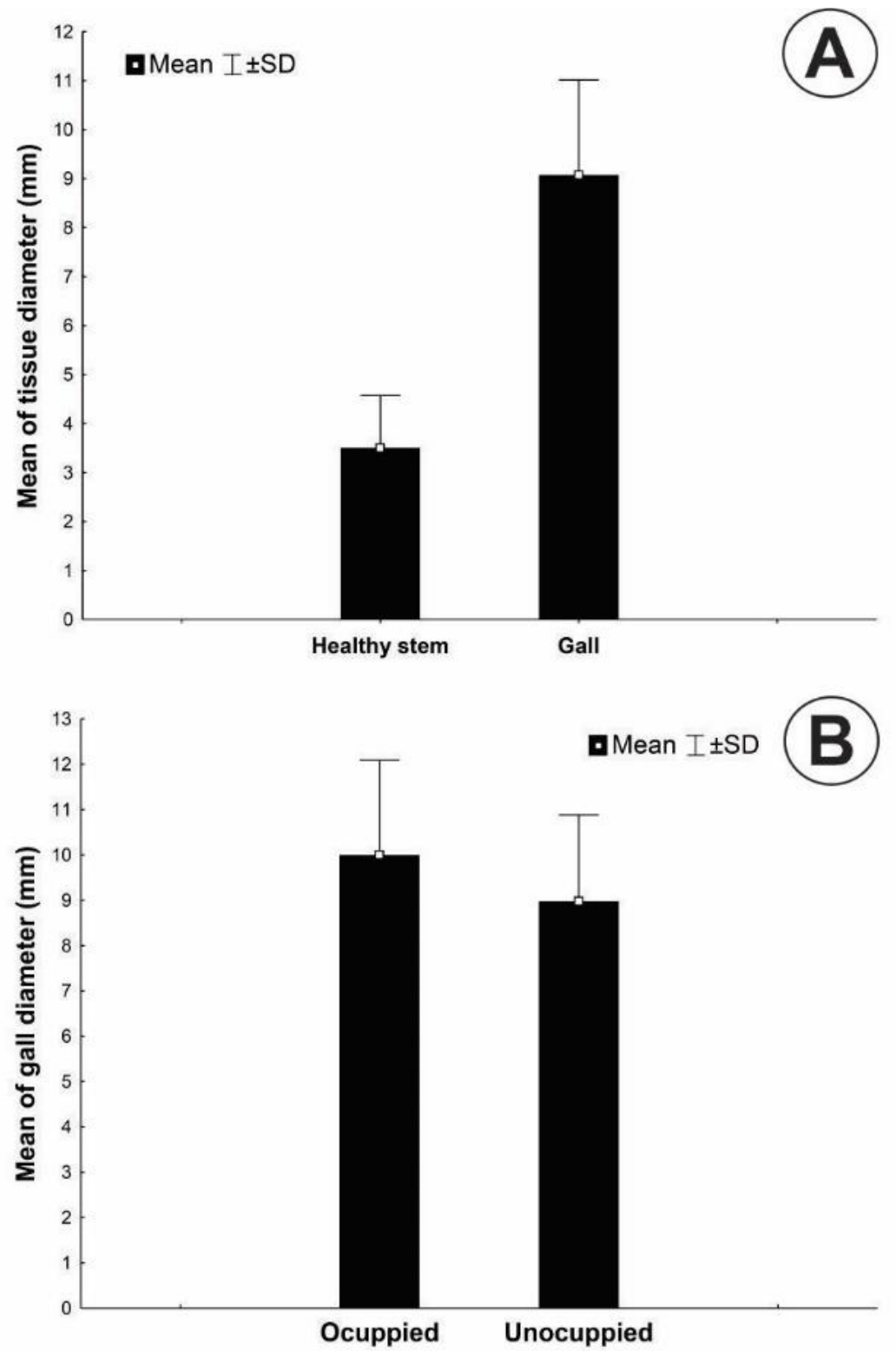

Figure 2. Difference between: A. mean of diameter of healthy stems and galls inducing by a cecidomyiid species on Eremanthus erythropappus (DC.) Mac. Leish (Asteraceae); B. mean of gall diameter of unoccupied and occupied gall by ant species. Font: Santos, J. C. (2021).

Galls commonly harbour secondary users and ants seem to be very common inhabiting galls. This opportunistic use of microhabitat are recorded in galls induced by distinct taxonomic groups, including many insect taxa (Fernandes et al., 1988; Araújo et al., 1995; Crawford et al., 2007), nematodes (Maruyama et al., 2012) and bacteria (Yamazaki \& Sugiura, 2008). Nevertheless, records of ant nests with queens and larvae in galls are rarer, and are mostly found in insect induced galls (Wheeler \& Longino, 1988; Craig et al., 1991; Araújo et al., 1995).
Myrmelachista gallicola was the most frequent ant species found in the cecidomyiid galls on E. erythropappus. The study broadens the previously known distribution of this species, which were only recorded in the Brazilian states of Rio Grande do Sul and Rio de Janeiro (Quirán \& Martínez, 2006). This species is commonly found inhabiting galls induced by Cecidomyiidae and Cynipidae and first individuals described were found inhabiting cynipid galls in species of Fabaceae (Quirán \& Martínez, 2006). Almeida et al. (2014) found an unidentified species of 
Myrmelachista that can belong to the species $M$. gallicola. If this ant species is somehow specialized in inhabiting galls or not, it seems to be an interesting question to be addressed in future studies.

The space created by galls can attract ants for nesting. As in our study, Almeida et al. (2014) found that $14 \%$ galls on E. erythropappus were occupied by eight different ant species. The cecidomyiid midge induced galls enlarged the stems of the host plant, E. erythropappus. Thus, gall inducer increased the space available for ants (Craig et al., 1991; Araújo et al., 1995, Almeida et al., 2014), and might offer protection against predators and unfavourable environmental conditions (Hawkins \& Unruh, 1988; Larsson et al., 1997, Fukui, 2001; Crawford et al., 2007). Gall inducers can have an important role in the diversity of arthropods associated to their host plants, and as such, act as ecosystem engineers (Jones et al., 1997; Crawford et al., 2007; Maruyama et al., 2012; see also Fernandes et al., 1999). In this sense, gall inducers might have a diversity enhancing effect where they are abundant, especially for opportunistic cavity dwellers, such as ants.

\section{Conclusions}

Abandoned galls in Eremanthus erythropappus act as "micro" ecosystem engineers, creating new habitats and promoting the abundance and diversity of opportunistic dwellers, such as ant species.

\section{Acknowledgements}

Authors thank Tiago M. Frizzo and Rodrigo Machado Feitosa (Laboratório de Sistemática e Biologia de Formigas - Universidade Federal do Paraná) for sharing information about ant species. Thank the support of $\mathrm{CNPq}$ and FAPEMIG, and the grants provided by Fapemig (Process APQ-02543-10) and CNPq (\#140128/2019-0).

\section{References}

Almeida, M. F. B.; Santos, L. R.; Carneiro, M. A. A. 2014. Senescent stem-galls in trees of Eremanthus erythropappus as a resource for arboreal ants. Rev. Bras. Entomol., 58, 265272.

Araújo, L. M.; Lara, A. C. F.; Fernandes, G. W. 1995. Utilization of Apion sp. (Coleoptera Apionidae) galls by an ant community in southeastern Brazil. Trop. Zool., 8, 319-324.

Coelho, M. S.; Carneiro, M. A. A.; Branco, C.; Fernandes, G. W. 2013. Gall-inducing insects from Serra do Cabral, Minas Gerais, Brazil. Biota Neotrop., 13, 102-109.
Craig, T. P.; Araújo, L. M.; Itami, J. K.; Fernandes, G. W. 1991. Development of the insect community centered on a leaf bud gall formed by a weevil (Coleoptera: Curculionidae) on Xylopia (Annonaceae). Rev. Bras. Entomol., 35, 311-317.

Crawford, K. M.; Crutsinger, G. M.; Sanders, N. J. 2007. Host-plant genotypic diversity mediates the distribution of an ecosystem engineer. Ecology, 88, 2114-2120.

Fernandes, G. W.; Boecklen, W. J.; Martins, R. P.; Castro, A. G. 1988. Ants associated with a coleopterous leaf-bud gall on Xylopia aromatica (Annonaceae). P. Entomol. Soc. Wash., 91, 81-87.

Fernandes, G. W.; Fagundes, M.; Woodman, R. L.; Price, P. W. 1999. Ant effects on threetrophic level interactions: plant, galls, and parasitoids. Ecol. Entomol., 24, 411-415.

Fukui, A. 2001. Indirect interactions mediated by leaf shelters in animal-plant communities. Popul. Ecol., 43, 31-40.

Giannetti, D.; Castracani, C.; Spotti, F. A.; Mori, A.; Grasso, D. A. Gall-colonizing ants and their role as plant defenders: From 'bad job' to 'useful service'. Insects, 10, 392, 1-19.

Hawkins, B. A.; Unruh, T. R. 1988. Protein and water levels in Asphondylia atriplicis (Diptera: Cecidomyiidae) galls. Southwest. Nat., 33, 114-117.

Jones, C. G.; Lawton, J. H.; Shachak, M. 1997. Positive and negative effects of organisms as physical ecosystem engineers. Ecology, 78, 1946-1957.

Larsson, S.; Haggstrom, H.; Denno, R. F. 1997. Preference for protected feeding sites by larvae of the willow-feeding leaf beetle Galerucella lineola. Ecol. Entomol., 22, 445452.

Mani, M. S. 1964. Ecology of plant galls. Dr. W. Junk, The Hague.

Maruyama, P. K.; Nahas, L.; Moura-Neto, C.; Santos, J.C. 2012. Gall-inducing nematodes as ecosystem engineers for arthropods associated with its host plant in the Cerrado of Brazil. Stud. Neotrop. Fauna E., 47, 131138.

Quirán, E. M.; Martínez J. J. 2006. Redescripción de la obrera de Myrmelachista gallicola (Hymenoptera: Formicidae) y primera cita para la provincia de La Pampa (Argentina). Rev. Soc. Entomol. Arg., 65, 89-92.

Sanver, D.; Hawkins, B. A. 2000. Galls as habitats: the inquiline communities of insect galls. Basic Appl. Ecol., 1, 3-11.

Sugiura, S.; Yamazaki, K. 2009. Gall-attacking behavior in phytophagous insects, with 
emphasis on Coleoptera and Lepidoptera. Terr. Arthropod Rev., 2, 41-61.

Wheeler, J.; Longino, J. T. 1988. Arthropods in live oak galls in Texas. Entomol. News, 991, 2529.
Yamazaki, K.; Sugiura S. 2008. Arthropods associated with bacterium galls on Wisteria. Appl. Entomol. Zool., 43, 191-196.

Zar, J. H. 1999. Biostatistical analysis. Upper Saddle River (NJ), Prentice-Hall, Fourth edition. 